\title{
The 'Comedy of a Duke of Ferrara' in 1598
}

\begin{abstract}
The 'Comedy of a Duke of Ferrara' is a title of convenience for a lost play associated with the Englische Komödianten in Germany in 1604. It appears to be linked to an extant German play, Tiberius und Annabella, and therefore to John Marston's The Fawn. This essay discusses a hitherto unnoted reference to the play in English print. The allusion acts as an anchor for all the other records and has implications, not just for the 'Comedy of a Duke of Ferrara', but also for Tiberius und Annabella, The Fawn, and - arguably — Shakespeare's Measure for Measure.
\end{abstract}

This essay concerns a nebulous and difficult creature: a lost play from the early modern English theatre, referred to, for convenience, under the title 'Comedy of a Duke of Ferrara'. Even by the standards of lost texts, this one is unusually tricky, since as Martin Wiggins observes, 'there are several dimensions to the problem of this play's identity'. It has no known title, hence the title of convenience; no known author; and no clear date of composition. The play is apparently recorded in four primary documents, all from the activities of the Englische Komödianten in Germany, and it also appears (to many scholars) to be a source for an extant German play, Tiberius und Annabella, which therefore makes it a key part of problems around the date and sources of an extant and much better-known English play, John Marston's comedy The Fawn. ${ }^{1}$ Our knowledge of it is only composite, combining clues from various different records only tenuously linked to one another, and this is far from satisfactory, both in general - one would like to know as much as possible about all the plays of early modern England, extant and lost - and specifically with reference to the problem of The Fawn.

All this is known already. But in this piece I discuss a hitherto unobserved reference in English print to what is clearly the same play. This allusion acts as an anchor for all the other records, seemingly confirming the play's English currency and offering more information about its characters and plot. This allusion is the springboard, here, for a fuller re-examination of the lost play and its related

Matthew Steggle (m.steggle@shu.ac.uk) is professor of English at Sheffield Hallam University. 
texts. The material offered here has implications not just for the 'Comedy of a Duke of Ferrara', a small but appreciable part of the known world of early modern English drama, but also for Tiberius und Annabella, The Fawn, and, arguably, another play of the period: Shakespeare's Measure for Measure.

This essay, then, is a specimen of what one might call lost play studies: the growing body of work looking at the over a thousand known lost plays of early modern drama, revisiting their textual traces with the aid of, in particular, the tools of digital humanities, and hoping to find there material which might modify our sense of early modern drama both in the details and as a whole. ${ }^{2}$

\section{Hecatonphila}

The new allusion presented here occurs in a prose work of 1598, Hecatonphila: The Art of Love, or, Love Discovered in an Hundred Several Kinds. After commendatory material, Hecatonphila opens with a four-page 'Argument' which begins as follows:

Vincentio Bentiuoli beeing Duke of Ferrara, a solemne contract of mariage was cốcluded, betweene Ludouico his Sonne, and faire Annabella, Daughter to the Marquesse of Mont-Ferrat. And when the tìme of the Nuptialls came to bee perfourmed, there wanted no resort of honorable Personages, nor anie magnificent cost and royall pompe, as might well beseeme a matter of such importance, as also the time so necessarily vrging it. ${ }^{3}$

One night, a group of these 'honorable Personages' are waiting for the evening's entertainment, a comedy. While the actors are preparing, a gentlewoman who calls herself Hecatonphila ('a hundred loves') gets up onto the stage and delivers a long speech to the young women present, a speech which appears under a fresh heading and actually takes up the whole of the rest of the pamphlet.

Hecatonphila's speech is about love. She warns against the distresses caused by improperly managed love and advises young women on how to achieve happiness by choosing a suitable lover. She counsels women to avoid both 'the yong Fantasticke' lover and the overly old; talks about the pleasures of secret love; and warns of the problems of running multiple lovers. She describes how she learned to deal with jealous feelings in her own love and marriage. Hecatonphila's monologue puts great stress on female emotions and female desire, and it starts from the welcome assumption that strong feelings do not make one an unvirtuous woman. On the other hand, the text is socially conservative in that the frame of reference 
is very narrow and there is no real reference to the social and economic pressures on women. Instead, as Nancy J. Vickers puts it: 'the program for female happiness she counsels lies largely in becoming lovingly subservient to an ideal male lover or husband - that is, to a middle-aged scholar of middle means'. ${ }^{4}$ At the end of this monologue, Hecatonphila announces that 'I see the Comedie is in some forwardnes, $\&$ the Personages ready attyred that are to present it', and comes to an abrupt conclusion. ${ }^{5}$

Now, the main body of the pamphlet is a translation of the prose tract Hecatomphila or Ecatomfilea, written in Italian by the scholar Leon Battista Alberti, and first printed in Milan in 1471. As the description so far suggests, this Italian text is an early member of the Renaissance tradition of courtesy books whose best-known example today is probably Castiglione's The Courtier. The Italian Hecatomphila enjoyed considerable success in the sixteenth century, and it was also popular in France, where its French translation, Hecatomphile, went through numerous editions. ${ }^{6}$ The 1598 edition under discussion here, which may well be via one of the French editions, is its first and for a long time its only appearance in English print.

While the French and Italian versions have had some critical attention, little has been said about the English Hecatonphila. It appears in catalogues of English translations from the Italian, and is occasionally mentioned in passing in the context of surveys of contemporary advice on female behaviour. ${ }^{7}$ The book as a whole is dedicated to Henry Prannell, whose young wife would go on to be famous as duchess of Lennox and Richmond, and some critics see the publication as a possible compliment to her. ${ }^{8}$ Furthermore, being essentially a dramatic monologue on erotic and comic themes, one might expect the English Hecatonphila to occupy a cultural space fairly close to that of early modern drama, and this is indeed in broad terms the case, certainly as regards the English edition. At least three of the individuals involved in the 1598 publication are linked to early modern drama. Peter Short, the printer, had already been involved in printing several Shakespeare quartos. William Leake, the stationer of the book, also published drama including The Death of Robert, Earl of Huntington (1601). A Latin dedicatory poem to the collection is written by 'Franciscus Meres', that is, Francis Meres, famous to posterity principally for his detailed discussion of current drama in Palladis Tamia (1598). ${ }^{9}$ Hecatonphila, then, belongs broadly to the milieu of English drama around 1598.

But it is unobserved in any of the sources cited above that the English version differs significantly from its continental originals. The French and Italian versions have no framing material to introduce the woman's monologue, and consist 
solely of the first-person speech. The explanatory Argument set at the Ferraran court has not yet been traced in any form of the story circulating before 1598, and appears to be original to the English version. ${ }^{10}$ Brief though it is, that first sentence in particular is interesting because it invokes four characters:

- Vincentio Bentivoli, duke of Ferrara. There are hitherto no known references to any historical or fictional duke of Ferrara named Vincentio (with the possible and controversial exception of Shakespeare's Measure for Measure, of which more later); nor to any historical or fictional dukes of Ferrara from the Bentivoli family; nor to any historical individual named 'Vincentio Bentivoli'. There is, however, a fictional one, extant by 1598 , since 'Vincentio Bentivoli' is a character from a Shakespeare play. In The Taming of the Shrew, it is the name of Lucentio's Pisan father, who exposes the disguises of his prodigal juniors; forgives them their indiscretions; and takes part in his son's wedding-feast at the end of the comedy. The historical Bentivoli were neither from Pisa nor from Ferrara, being in fact a wealthy and politically shrewd family associated primarily with Bologna. ${ }^{11}$

- Ludovico Bentivoli, son of the duke of Ferrara. Again, there are no obvious historical or fictional figures bearing this name.

- The marquess of Montferrat. Montferrat is a small territory in Northern Italy, and its ruler, the marquess, is alluded to frequently in earlier Tudor texts including, once again, Shakespeare. He is mentioned, for instance, in The Merchant of Venice, since it was in his company that Portia first saw Bassanio (1.2.98). And the reference is tellingly obsolete, since the title of marquess of Montferrat ceased to exist in 1574, being upgraded to duke of Montferrat. By the 1590s, the marquess of Montferrat is for Shakespeare and Hecatomphila very much a literary idea rather than a reflection of current affairs in Italy.

- Annabella, daughter of the marquess of Montferrat. Again, no historical namesake can be found.

All four of these characters seem to be from the same lost play, the 'Comedy of a Duke of Ferrara'. 


\section{The 'Comedy of a Duke of Ferrara'}

Briefly, at least two and perhaps as many four separate documents appear to describe the 'Comedy of a Duke of Ferrara'. All of the documents concern the activities of the Englische Komödianten, English professional actors touring in Germany. The first task is to describe these archival records, in order to restate the grounds on which scholars so far have felt justified in assuming that they belong to the same play.

Groups of English professional actors were visiting the continent from as early as 1580 s, and continued doing so until the later seventeenth century. As Pavel Drábek and M.A. Katritzky observe, there are many difficulties in tracing the activities of the Englische Komödianten, whose activities must be understood in a pan-European, rather than just an English, context. The archival records of them are fragmentary, and the plays they presented, while clearly in many cases versions of ones originating in the English professional theatre, were equally clearly remade and reinvented for continental audience expectations. Scholars have long neglected the phenomenon of the Englische Komödianten. But these actors, argue Drábek and Katritzky, in fact 'made a lasting impact on the theatrical cultures of mainland Europe' as well as bringing European culture back to the English theatre. $^{12}$

On 18 January 1604, one group of touring actors petitioned the authorities at Nördlingen, deep in Southern Germany and on the edge of the duchy of Württemburg, for permission to perform. They listed their repertoire of ten plays, including a play about Romeo and Juliet, and one described as 'vonn Annabella eines hertzogen tochter von Ferrara' [of Annabella, daughter to a duke of Ferrara]. This petition was rejected by the town authorities, but is recorded in their archives. ${ }^{13}$

The Nördlingen petition has long been linked, on paleographical and other grounds, to two other, undated petitions in the archives of the town of Rothenburg ob der Tauber, fifty miles away and also on the edge of the duchy of Württemburg. In these two documents, an unnamed group of comedians offer a total of twelve plays for performance, several of which correspond to the ten on the Nördlingen list. Among the Rothenburg titles is a play 'vonn Annabella, Eines Margraffen tochter von Montferrat' [of Annabella, daughter to a margrave of Montferrat]. ${ }^{14}$ The usual scholarly assumptions, which I do not propose to challenge here, are that the two Rothenburg lists result from the activities of the same group of English comedians, probably the company of Robert Browne, formerly of the Admiral's Men; that they are contemporary with the Nördlingen list, 
which is also Robert Browne's company; and that the two plays about a daughter called Annabella are in fact different descriptions of the same play.

For the purposes of the argument here, the Nördlingen and Rothenburg petitions are all that is actually needed to clinch the point. But two other records are usually, and not unreasonably, 'lumped' with these two - assumed, that is, to belong to the same play - and I list them here too. As has long been observed, the play described in the Nördlingen petition seems plausibly to connect with that mentioned in a record, in 1597, of Englische Komödianten performing at Strasbourg. The comedians there were under the leadership of Thomas Sackville. On 25 July Baron Waldstein watched them perform Comoediae, ab Anglis factae de quodam Duce Farrari, 'comedies made by the English about a certain Duke of Ferrara'. ${ }^{15}$ Another English company, at Dresden in 1626, twice performed a play recorded as 'Comoedia vom Hertzog von Ferrara' [the comedy of a duke of Ferrara], and again Ockham's razor has suggested to most scholars that this too is a manifestation of the 1604 lost play. ${ }^{16}$ There is probably, then, a long-lived and successful comedy recorded in these four documents, which is otherwise lost. The assumption is, too, that it has an origin in the English theatre, although at the moment this is still hedged with uncertainty: hence Martin Wiggins's description of it as 'possibly non-Catalogue'. ${ }^{17}$

But combining as it does a duke of Ferrara, a marquess (that is, margrave) of Montferrat, and a daughter named Annabella, the Argument to Hecatonphila clearly has something to do with that lost play. It acts, indeed, as a much-needed frame, threading all the other records more firmly together. For instance, it reconciles the two contradictory German descriptions, since its Annabella is the margrave of Montferrat's daughter, and also the duke of Ferrara's daughter by marriage (pleasingly, this is exactly the solution conjectured by Martin Wiggins before the Hecatonphila reference was known). In its reference to marriage, it also confirms, fairly conclusively, that the 1604 records do indeed refer to a comedy, which helps to link in the 1597 and 1626 records. Being considerably earlier than those 1604 records, it suggests that the 'Comedy of a Duke of Ferrara' was in existence by 1598 , something which closes the gap between 1604 and the play recorded in Germany in 1597. And being a reference to the story in English, it tends to suggest that the play did indeed have an origin in the English theatre before being taken on tour.

Perhaps the easiest way to visualize how this web of correspondences has been reinforced is in a table [Figure 1]. To summarize, the 'Hecatonphila' allusion helps by providing further scaffolding for the existing scholarly suggestion that these various disparate records actually refer to the same play. 


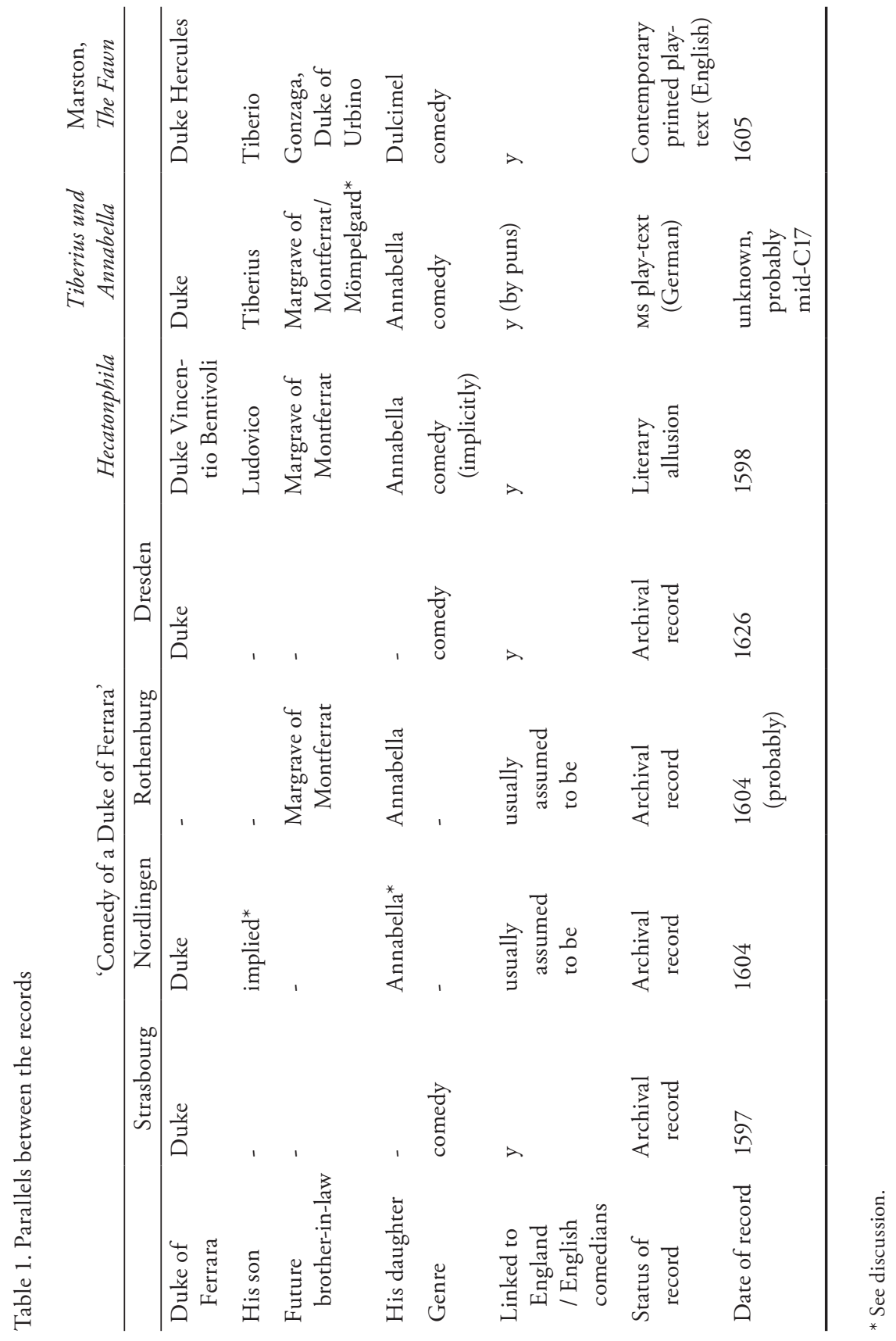




\section{Tiberius und Annabella}

As a successful and seemingly long-lived lost play from Shakespeare's era, the 'Comedy of a Duke of Ferrara' should be of interest anyway, but what gives it particular spice is that it may be preserved, at least in part, in a German comedy, also untitled and called, by its nineteenth-century editor, Tiberius von Ferrara und Annabella von Mömpelgard. ${ }^{18}$

Tiberius und Annabella is problematic on many counts, not least that it is very hard to date, beyond the fact that it survives in a manuscript found among the literary remains of Georg Schröder, who was not even born until 1635. Specifically, it is now Gdansk: Stadtbibliothek, Ms 2421, ff 65-86. It is one of a large group of German-language plays that appear to be linked to the activities of the English comedians, the most famous members of which are the collection of plays printed at Leipzig in 1620, Engleische Comedien vnd Tragedien. After decades of critical neglect, in very recent years new research projects are starting to address these plays, which are important documents of European cultural exchange. They seem to hold out the promise of revealing much about early modern European theatre potentially including — as here — material from otherwise lost plays of early modern England. ${ }^{19}$

As Drábek and Katritzky warn, however, it is too simplistic to see these texts merely as plays based on English originals. Rather, they argue, these texts are in some senses mementoes of ideal performances: 'they are not simply dramatic texts but intertextual records mediating between their English and continental pretexts and the performances resulting from them. ${ }^{20}$ That is a particularly interesting formula to apply to Tiberius und Annabella whose text, as we shall see, has one obvious internal inconsistency that would surely have been ironed out in any attempt to perform it as it stood. This very warning of the distance between the German plays and their putative English originals makes the various connections that can be established between Tiberius und Annabella and our lost play all the more striking.

It has long been known that Tiberius und Annabella has similarities to what can be discerned of 'The Comedy of a Duke of Ferrara', and these similarities are made clearer by the extra information now available in the Hecatonphila allusion. Tiberius und Annabella features a duke of Ferrara; a margrave; and Annabella, daughter of the margrave, who ends up marrying the duke of Ferrara's son. These four characters map closely onto the four characters now known in connection with the 'Comedy of a Duke of Ferrara', as the table shows.

As for its plot: in the German play, the widowed duke of Ferrara sends his son, a bachelor, to Mömpelgard, to woo the daughter of the margrave on his 
father's behalf. Unknown to anyone, the duke follows, taking on the disguise of an old soldier named Bartholomaeus, and watches developments. The margrave welcomes the young man and introduces him to his daughter to conduct the wooing, but very quickly Annabella falls in love with the young man, and he with her. Alongside this action, there are a series of comic scenes containing the clown Hans Leberwurst, a staple of plays associated with the Englische Komödianten and traceable from around 1615 onwards. Evidently these scenes are written for a German audience.

In the face of parental opposition, Annabella disguises herself as a man and elopes with her lover. The disguised duke of Ferrara then intervenes, taking on a new disguise as a hermit and inviting them into his cave, under the pretext of carrying out their marriage ceremony. In fact he takes the opportunity to kidnap Annabella. The lovers escape again by a dancing trick, only to drown, as it appears, while crossing a river. The duke and margrave lament their loss, before it is revealed that the lovers are still alive, and all are reconciled.

As well as the quartet of characters, there are other clues that the German text is based, at least in part, on an English original. For instance, it appears in the Gdansk manuscript alongside a play which adapts Gervase Markham's The Dumb Knight, another play known to have been acted by the Englische Komödianten. The play's nineteenth-century editor Johann Bolte also notes an intriguing moment in act 4, where the disguised Duke is trying to get some sense out of the comic nurse Hagewoll. Hagewoll mishears words, interpreting, for instance, 'Ferrara' as 'Tentara', and also misunderstands a question from the Duke:

Dux [W]o ist das Frewlein Annabella?

HAGEWOLL Die Klocke gesch[l]agen?

[DUkE Where is the Lady Annabella?

HAGEWOLL Has the clock chimed?]

(Tiberius und Annabella, 4.4)

This exchange makes no sense in German but would work in English, with the pun on 'Annabella' and 'a bell'. 21

Another moment when the play is caught in the act of adaptation relates to its geographical setting. According to the dramatis personae and a couple of references early in the play, Tiberius und Annabella takes place in Mömpelgard, that is, modern Montbéliard in eastern France, the wrong side of the Alps from Ferrara. The fact that it is set in Mömpelgard, and not in Montferrat, has been considered 
as a potentially insurmountable obstacle to connecting the play to the 'Comedy of a Duke of Ferrara' at all.

But fresh re-examination shows that this location is a late and half-hearted revision to the German play. Mömpelgard was never a margravate, and there is no reason for the play to make it one. Also, the denouement takes place on the river Susa, which is a great deal closer to Montferrat than to Montbéliard. Tellingly, as the play goes on, references to Mömpelgard peter out and the dialogue itself starts to refer to the location not as Mömpelgard but as Montferrat. Indeed, 5.11 refers to the Margrave himself as 'der Marckgrave von Montferar'. ${ }^{22}$ These incomplete revisions show that the writer is working from some pre-existing text set in Montferrat. Furthermore, as one of the anonymous readers of Early Theatre has pointed out, Mömpelgard is a city of particular interest to the duchy of Württemburg, the southern touring hub of the English comedians (and both Rothenburg and Nördlingen lie on the edge of that duchy). The county of Mömpelgard was a distant but valuable possession of the ducal family, and indeed between 1593 and 1617, the duke of Württemburg was also count of Mömpelgard. One would not want to make anything of that connection in terms of dating the change of location, but the wider point is that the move to Mömpelgard arguably makes the play more relevant for German audiences.

And there is one further continuity to note between the German text and the earlier records. In Tiberius und Annabella, Annabella falls in love at once and expresses her desire first, and Annabella takes the initiative to elope. This fits with the 'Comedy of the Duke of Ferrara' insofar as two of the records of that play name her as the eponymous character of the play. It also fits with the Hecatonphila allusion, where Annabella's wedding is thought to be a suitable pretext to introduce a discourse about female desire, managing men, and achieving marriage. Annabella is no mere love trophy, but an active heroine.

Given the matching quartet of characters, and the shared name 'Annabella'; the seemingly congruent theme of female agency; the evidence of a layer of perfunctory geographical revision; and the fossilized English pun in act 4, it is possible that Tiberius und Annabella as we have it may remain in parts a fairly close reporting of the lost 'Comedy of a Duke of Ferrara'. Certainly it would not be incompatible with what information there is about that play's content and mood, especially now that that information is reinforced by the 1598 Hecatonphila allusion. But the complicating factor here is the German play's relationship with an English comedy of 1604 or 1605, Marston's The Fawn. ${ }^{23}$ 


\section{Parisitaster, or The Fawn}

As the table illustrates once again, Marston's play too features a recognizable foursome of central characters led by the Duke of Ferrara. Its 'away' location is not Montferrat or Mömpelgard but that quintessentially Italian city Urbino, and it differs in a couple of the proper names - although, strikingly, the duke of Ferrara's son shares his name with that of his German counterpart. ${ }^{24}$ In The Fawn, as in Tiberius und Annabella, the widowed duke of Ferrara sends his avowed bachelor son to a neighbouring court to woo a bride on his father's behalf. This time the bride in question is Dulcimel, the witty and passionate daughter of the foolish duke of Urbino. As in the German play, the duke of Ferrara follows along, this time disguising himself as an intelligencer and taking the name Faunus. As in the German play, the two young people fall in love with each other even while the son is trying to represent his father's suit. In the course of the play the clever daughter (this time with the disguised duke of Ferrara's help) finds a way to outwit her father and marry Tiberio.

The Fawn is similar, then, to Tiberius und Annabella in its setup, and it even has some passages strikingly parallel to the German. Both plays, for instance, include a scene in which the duke of Ferrara explains his plan and appoints a deputy to look after the country in his absence (The Fawn, 1.1; Tiberius und Annabella, 1.4). Both have a scene where Annabella's/Dulcimel's father receives the young man and introduces his daughter. And in both plays the young man produces his father's portrait, only to find that Annabella/Dulcimel falls in love with him instead. ${ }^{25}$

The German version of this last scene includes the passage:

anabella Gantz nicht, gnediger Herr, sondern ich beschawe E. Gn. Herrn Vatem

Contrafactur. Ist es ihm auch ehnlich.

Tiberius Ja, gnediges Frewlein, alss wen Ihr ihn selber zugegen sehet.

ANABella Ist es muglich, ein so durrer Baum vndt so schöner Zweich! Wie aldt ist er woll?

TIBERIUS Irgend vierzig Jahr.

ANABELla Ja, da diess gemahlt ist; dan die Hende scheinen gahr zu dürre. Ich muss bekennen, gnediger Herr, E. Gn. Herr Vater hette keinen bessern Agenten finden konnen, der so fleisich sollicitiret hette, vndt mochte wünschen, das E. Gn. diese Muhe nach meinem Begehren belohnet wurde, vndt soldt ich gleich selbst die Besoldung sein. 
[ANABElla Not at all, dear sir, but let me see your father's counterfeit. Is it like him?

TIBERIUS Yes, dear lady, as if I presented you to him myself.

ANABELLA Is it possible, so dry a tree and so beautiful a branch! How old is he, about?

TIBERIUS About forty years.

ANABELla Yes, that is painted there; the hands seem so thin. I must confess, dear sir, your honoured father could not find a better agent who could solicit so diligently, and I might wish that your effort was rewarded by winning my desire, though I myself should be the reward.] ${ }^{26}$

(Tiberius und Annabella, 2.1)

Compare the corresponding exchanges in Marston:

DUL. Is this your father's true proportion? Shows a picture.

тів. No, lady, but the perfect counterfeit.

DUL. And the best graced -

тIв.

The painter's art could yield.

тів. Why, fairest princess, if your eye dislike

That deader piece, behold me his true form

And livelier image, such my father hath been.

DUL. This model speaks above forty.

тів. Then doth it somewhat flatter, for our father hath seen more years, and is a little shrunk from the full strength of time.

GON. Somewhat coldly praised.

DUL. Your father hath a fair solicitor, And be it spoke with virgin modesty,

I would he were no elder.

(Parasitaster, 1.2.107-10, 116-18, 136-42)

In the context of the shared names and place names, these passages seem so close as to suggest something more than mere shared cliché. And yet equally striking is 
the fact that after this shared opening gambit, the two plays diverge radically, with Marston's taking a plot from Boccaccio which has no parallel in the German. ${ }^{27}$

Given this as a starting point, one might become suspicious about other aspects of Marston's play, which itself bears some marks of imperfection. The dramatis personae, for instance, begins, not with all the male characters, nor with characters in order of appearance, but with the central quartet of Duke of Ferrara, son, Duke of Urbino, and daughter. Fifth on the list comes Philocalia, who appears to be intended as a new love interest for the Duke of Ferrara, although she drops out from the last scene of the play and the plotline is never resolved. After Philocalia comes the large cast of fools who in practice fill most of the play with action which hardly impinges on the main plot. Functionally useful characters such as the Duke's brother Reynaldo (who makes a single appearance in 1.1) are then added as afterthoughts. It is almost as if Marston is starting with the four principals; bolting on Philocalia; and then developing the fools.

And all this bears, of course, on the question of how Marston's play relates to the 'Comedy of a Duke of Ferrara'. As Martin Wiggins puts it:

If the play in the records is the one which survives at Gdansk, then it or its English original must be the direct source of The Fawn; but if the Gdansk play is taken to be an adaptation of The Fawn, it cannot be the same play that was performed in 1597 or 1604, before The Fawn was written. ${ }^{28}$

One solution to this has been to see Tiberius und Annabella as basically a free adaptation of The Fawn, borrowing a name or two from the old 'Comedy of a Duke of Ferrara' along the way. ${ }^{29}$ But this seems harder to sustain given the material adduced here confirming that the 'Comedy of a Duke of Ferrara' already featured the central quartet of characters, and given Tiberius und Annabella's deep and partially erased links to Montferrat. It looks much more as if Tiberius und Annabella and The Fawn are both starting from the same lost play.

I began by saying that the 'Comedy of a Duke of Ferrara' was a particularly difficult and nebulous object, and so it remains. But we now have a clearer narrative about it, which can be retold in chronological order. In the 1590s, there was a successful English love comedy featuring the duke of Ferrara, his son, the marquess of Montferrat, and his daughter Annabella. The duke of Ferrara's son is sent to woo the marquess's daughter for his father, and she falls in love with him instead while the disguised duke of Ferrara, visiting Montferrat incognito, watches events unfold. A version of this play went to the continent with the English comedians, and we see traces of it in performance in southern Germany in 1604 - indeed, 
probably in 1597,1604 , and 1626 . That version mutated through its life, acquiring the clown Hans Leberwurst and being relocated to Mömpelgard, on its way to being preserved, to some extent, in the much later German Tiberius und Annabella. Meanwhile, back in England, the play was remembered in 1598 in the Argument to that courteously modest celebration of female desire, Hecatonphila. In 1604 or 1605, Marston returned to the old play and in effect cannibalized elements from its opening sections to be the starting point for another quite different comedy. All this fits with what is, in recent years, becoming the new narrative about early modern play-texts: that they are not at all stable literary objects, but very fungible, mutable items. Even Marston, often regarded as a clear example of a solitary and distinctive authorial voice, is part of this system. ${ }^{30}$

\section{Measure for Measure}

This would be the end of the story, except that there is one other interesting feature about Hecatonphila's fictional duke: as noted above, he is a duke Vincentio of Ferrara.

Famously, the Viennese Duke of Measure for Measure also bears the first name 'Vincentio', or at least he is given that name in the dramatis personae appended to the text as published in the First Folio of 1623, although the name appears nowhere in the text of the play proper. Samuel Johnson deduced that 'It is therefore likely that there was then a story of Vincentio Duke of Vienna', but, in spite of much subsequent research, no such story, historical or fictional, has been identified. ${ }^{31}$ This is perhaps not surprising given that Vincentio's name is so clearly Italian sounding, and indeed the Italianness of this and the other names in the play is a mainstay of the argument, advanced in particular by Gary Taylor and John Jowett, that the play was originally set by Shakespeare in Italy before being relocated to Vienna as part of a set of extensive later revisions by Thomas Middleton. ${ }^{32}$

In particular, Taylor offers the brilliant conjecture that the play was originally set in Ferrara, a city metrically equivalent to Vienna. ${ }^{33}$ Ferrara, he observes, is the location for some versions of one of the play's sources; and it features frequently elsewhere in Renaissance English drama, including two disguised-duke comedies contemporary with Measure for Measure, namely The Fawn and Middleton's The Phoenix. The hypothesis of an 'original' 1604 Measure for Measure, set in Ferrara and partly recoverable from under the later revisions of the Folio, remains controversial, but it is gaining significant traction both in scholarly work and in theatre productions. ${ }^{34}$ Samuel Johnson, in these circumstances, would look for a story of Vincentio, duke of Ferrara, and none has yet been adduced. 
But this passage from Hecatonphila does indeed supply such an example. It confirms that around the original date of Measure for Measure 'Vincentio' is indeed a plausible name for a fictional duke of Ferrara. And it offers evidence that Ferrara might indeed, in the early modern English imagination, be seen not merely as a place for the knockabout satire of The Phoenix, but also as a location fit for serious discussion of the turbulent and mysterious nature of desire, love, and marriage, particularly from the perspective of women.

Were it more certain that the 1604 Measure for Measure was indeed set in Ferrara, it would be interesting to consider Shakespeare's play further relative to this complex of texts: Tiberius und Annabella, The Fawn, and their putative joint parent the 'Comedy of a Duke of Ferrara'. Both the extant plays feature, as their lead characters, a spirited heroine and a notably older disguised duke of Ferrara whose relationship to her is not entirely age-appropriate (both dukes originally consider marrying her; Marston's then helps her lure a man up to her bedroom; Tiberius und Annabella's kidnaps her while pretending to be a holy man). If Measure for Measure were set in Ferrara, it might well be taking part in an existing discourse about Ferraran 'old fantastical Duke[s] of dark corners' (4.3.150).

But this would be to have one's cake and eat it too: this article concludes with the observation that Hecatonphila's fictional duke Vincentio of Ferrara might support the existing suggestion that Measure for Measure's Duke Vincentio, too, was originally Ferraran. As for the 'Comedy of a Duke of Ferrara', that play is now slightly better constrained than it was before, and hopefully more traces of it may yet come to light in other allusions to it or in more detailed study of its analogues.

\section{Notes}

1 Martin Wiggins, in association with Catherine Richardson, British Drama 15331642: A Catalogue (Oxford, 2012- ), item 859, using the title 'Comedy of a Duke of Ferrara'; earlier discussion by Gertrude M. Sibley, under the title 'Annabella eines Hertzogen Tochter von Ferrara', in The Lost Plays and Masques, 1500-1642 (Ithaca, 1933), 196; Harbage calls it 'Annabella, a Duke's daughter of Ferrara (usually identified as Marston's Parasitaster)': Alfred Harbage, rev S. Schoenbaum, rev Sylvia S. Wagonheim, Annals of English Drama, 975-1700, 3rd edn (Cambridge, 1989), 214.

2 For a more developed manifesto, and the figures quoted here, see David McInnis and Matthew Steggle (eds), Lost Plays in Shakespeare's England (London, 2014); see also the Lost Plays Database, http://www.lostplays.org.

3 Leon Battista Alberti, Hecatonphila (London, 1598), A7r-A7v. 
4 Alberti, Hecatonphila, 7; Nancy J. Vickers, 'The Unauthored 1539 Volume in which is Printed the Hecatomphile, The Flowers of French Poetry, and Other Soothing Things', in Margreta de Grazia, Maureen Quilligan, Peter Stallybrass (eds), Subject and Object in Renaissance Culture (Cambridge, 1996), 166-88, qtn from 174-5.

5 Alberti, Hecatonphila, 40. This line is indeed present in the Italian and French versions: Alberti seems to imagine Hecatonphila's speech as a public oration, not unlike The Praise of Folly.

6 Vickers, 'The Unauthored 1539 Volume', 166-88.

7 For example, Soko Tomita, A Bibliographical Catalogue of Italian Books Printed in England 1558-1603 (Farnham, 2009), 411-12.

8 Donald W. Foster, 'Stuart, Frances, Duchess of Lennox and Richmond (15781639)', Oxford DNB (Oxford and New York, 2004-), http://dx.doi.org/10.1093/ ref:odnb/70952; and his earlier article, "'Against the Perjured falsehood of your tongues”: Frances Howard on the Course of Love', English Literary Renaissance 24 (1994), 72-103, http://dx.doi.org/10.1111/j.1475-6757.1994.tb01417.x. Foster suggests both Anthony Munday and Frances Prannell herself as the translator, but neither case is at all solid.

9 David Kathman, 'Meres, Francis (1565/6-1647)', Oxford DNB, http://dx.doi. org/10.1093/ref:odnb/18581.

10 For instance, it does not seem to appear in the ten versions described by Vickers, 'The Unauthored 1539 Volume'; it certainly does not appear in the 1534 Italian edition, https://books.google.co.uk/books?id=Dew6AAAAcAAJ; nor in the 1535 Italian edition, https://books.google.co.uk/books?id=9fFaAAAAcAAJ; nor in the 1537 French edition, https://books.google.co.uk/books?id=9ANRAAAAcAAJ.

11 William Shakespeare, The Taming of the Shrew, ed. Brian Morris (London, 1981), 1.1.13; Morris's note ad loc; Morris also notes that the Bentivoli feature frequently in Machiavelli. For an extremely comprehensive survey of the uses of Ferrara in early modern English literature, see Gary Taylor, 'Shakespeare's Mediterranean Measure for Measure', in Shakespeare and the Mediterranean, ed. Tom Clayton, Susan Brock, and Vicente Forés (Newark, 2004), 243-69.

12 Pavel Drábek and M.A. Katritzky, 'Shakespearean Players in Early Modern Europe' in Bruce R. Smith (ed.), The Cambridge Guide to the Worlds of Shakespeare (Cambridge, 2016), 1527-33, qtn from 1528. Thanks to Pavel Drábek for valuable conversations about this play.

13 The record in the Nördlingen archives is quoted from the transcription by Karl Trautmann, 'Die Älteste Nachricht über eine Aufführung von Shakespeares Romeo und Julie in Deutschland (1604)', Archiv für Litteraturgeschichte 11 (1882), 625-6; 
for the rejection, see George Oppitz-Trotman, 'Romeo and Juliet in German, 16031604', Notes and Queries 62 (2015), 96-8, http://dx.doi.org/10.1093/notesj/gju252.

14 Karl Trautmann, 'Englische Komödianten in Rothenburg ob der Tauber', Zeitschrift für vergleichende Literatur 7 (1894), 60-7; Oppitz-Trotman, 'Romeo and Juliet in German', 96-8.

15 Willem Schrickx, Foreign Envoys and Travelling Players in the Age of Shakespeare and Jonson (Wetteren, 1986), 330.

16 Emil Herz, Englische Schauspieler und englisches Schauspiel zur Zeit Shakespeares in Deutschland (Hamburg, 1903), 66.

17 Wiggins, Catalogue, item 859; Sibley, The Lost Plays and Masques, 196; the Englische Komödianten played much the same repertory for decades, a factor which makes the twenty-year gap more palatable.

18 Link first suggested by Wilhelm Creizenach in Die Schauspiele der englischen Komödianten (Berlin and Stuttgart, 1889); play transcribed and discussed by Johannes Bolte, Das Danziger Theater im 16. und 17. Jahrhundert (Hamburg and Leipzig, 1895), 171-218. The play is cited throughout from this edition. Bolte argues the play may be mid-seventeenth century in date, and also argues in favour of a connection to the 'Comedy of the Duke of Ferrara' (Das Danziger Theater, 175). Harbage, Annals, 215, is doubly inaccurate in calling this extant German play 'The Duke of Ferrara (based on Marston's Parasitaster)'.

19 For references, see Oppitz-Trotman, 'Romeo and Juliet in German'; also a new project under the leadership of Lukas Erne to prepare English translations of the early German plays linked to Shakespeare (pers. comm.); for an authoritative guide to recent work see Drábek and Katritzky, 'Shakespearean Players in Early Modern Europe'.

20 Drábek and Katritzky, 'Shakespearean Players in Early Modern Europe', 1532.

21 Tiberius und Annabella, 4.4 ( $\mathrm{p}$ 199).

22 Mömpelgard: in dramatis personae (twice); in 1.1; and in stage direction in 2.1. Montferrat: references in 1.2 (twice); 4.6; 5.11 (twice). The river Susa: 5.4, p 208. For another place-name which remains in need of definitive elucidation, see Bolte, Das Danziger Theater, 194.

23 On the exact dating of Marston's play see Wiggins, Catalogue, item 859: it would require very special pleading to imagine it out on tour in Nördlingen by 18 January 1604.

24 Urbino was made famous by Castiglione: on the location see William W.E. Slights, 'Touching the self: masturbatory Marston' in T.F. Wharton (ed.), The Drama of John Marston: Critical Re-visions (Cambridge, 1999), 100-23, qtn from 102. 
25 Documented by Bolte, Das Danziger Theater, and also by David A. Blostein in John Marston, Parasitaster: Or, The Fawn, ed. David A. Blostein (Manchester, 1978), intro 34-5. The play is cited from this edition.

26 Tiberius und Annabella, 2.1, p 184. Thanks are due to my colleagues Robbie Aitken and Niels P. Petersson for advice on the translation.

27 For existing discussion of sources, see Marston, Parasitaster, ed. Blostein, intro 3442.

28 Wiggins, Catalogue, item 859.

29 This is the interpretation ultimately preferred by Wiggins, Catalogue; Blostein, in Marston, Parasitaster, intro 34-5, concedes the possibility of some influence on Marston from the lost play, but also suggests that material from The Fawn could have been reintroduced into the German adaptation. This argument is not impossible, but is rendered less necessary by the material adduced here.

30 The instability of play-texts is powerfully argued by Tiffany Stern, Documents of Performance in Early Modern England (Cambridge, 2009); overviews of Marston studies include T.F. Wharton (ed.), The Drama of John Marston: Critical Re-visions (Cambridge, 1999); Rebecca Yearling, Ben Jonson, John Marston and Early Modern Drama: Satire and the Audience (Basingstoke, 2016).

31 Samuel Johnson, qtd in William Shakespeare, Measure for Measure, ed. Mark Eccles (New York, 1980), 3. The play is quoted thereafter from this edition. On generally recognized sources and analogues see Eccles (ed.), Measure for Measure, pp 311-92; and Kevin A. Quarmby, The Disguised Ruler in Shakespeare and his Contemporaries (Farnham, 2013).

32 See The Complete Works of Thomas Middleton, ed. Gary Taylor and John Lavagnino (Oxford, 2007), drawing on earlier work including Taylor, 'Shakespeare's Mediterranean Measure for Measure', and John Jowett, 'The Audacity of Measure for Measure in 1621', Ben Jonson Journal 8 (2001), 1-19.

33 Taylor, 'Shakespeare's Mediterranean Measure for Measure', esp. 256. Another incidental relevance of the 'Comedy of a Duke of Ferrara' and Tiberius und Annabella here is that the German text provides a useful parallel example of an entire play being relocated to a second, metrically equivalent, city.

34 See, for instance, Terri Bourus and Gary Taylor, 'Measure for Measure(s): Performance-testing the Adaptation Hypothesis', Shakespeare 10.4 (2014), 363-401, http:// dx.doi.org/10.1080/17450918.2013.868508; Richard Wilson, 'As mice by lions: Political Theology and Measure for Measure', Shakespeare 11.2 (2015), 157-77, http:// dx.doi.org/10.1080/17450918.2013.766255. 